\title{
PROCESSES OF SPATIAL REDISTRIBUTION OF POPULATION AND CHANGES IN EDUCATIONAL STRUCTURE OF POPULATION: CASE STUDY OF THE KOŠICE FUNCTIONAL URBAN REGION ${ }^{1}$
}

\begin{abstract}
The paper focuses on the changes in the processes of spatial redistribution of population in connection with the changes in the educational structure of population. The development of both attributes of population is examined by the case study of the urban region of Košice - the second largest city in Slovakia. Similarly with other urban regions of Central European major cities, the process of centralization of population from the region's ring to its core changed into the decentralization, during the 1990s. While the natural reproduction of population allowed for population growth of the region as whole, the migration was the driving force of the spatial redistribution of population within the region. Along with the general changes in the educational structure of population related to transformation of educational system recorded in all Visegrad countries, research proves close relations between changes in educational structure of population and the processes of spatial redistribution of population at the intra-regional level of the Košice functional urban region. Changes in the proportion of population with elementary education as the highest educational level attained seem to be affected more by the natural reproduction of population, while the changes in the proportion of population with tertiary education indicate stronger relation with the migration development.
\end{abstract}

Key words: education, natural reproduction, migration, population, urban region, Košice.

\section{Introduction}

Post-socialist transformation underwent by Visegrad countries has significantly affected also the processes of spatial redistribution of population. Natural reproduction of population formerly characterized by significant natural increase of population changed into the pattern characterized by sub-replacement fertility and very low or even negative values of net reproduction rate. Changes in

${ }^{1}$ The results presented in this paper are an outcome of the project VEGA 1/0473/14: „Dynamic 3-D modelling of urban landscape with a multiscale approach”. 
migration trends were affected by termination of state-regulatory measures and the transition to democracy and free market economy. These changes affect the spatial redistribution of population as well as its cultural and social characteristics, including its educational structure.

As emphasized by J. Nestorová-Dická (2013), the education and educational structure of population in Visegrad countries as one of the key attributes of the state, regional or even local competitiveness has undergone substantial changes during the post-socialist transformation. These changes are related with transformation of educational systems in all Visegrad countries as well as with the changes in demographic behaviour of population. Despite some differences, many similarities were observed in the development in Czech Republic, Hungary, Poland and Slovakia. These include significant decline in the number and proportion of population with the elementary education as the highest educational level attained; the quantitative growth of secondary and especially higher education and the rate of population with university education; implementation of Bologna system and others (Jung-Miklaszewska 2003; Gorga 2007; Berde and Ványolós 2008; László 2008; Šprocha 2010; Lauko et al. 2012; Vincze and Harsányi 2012; Nestorová-Dická 2013).

The spatial distribution of the population by educational attainment has certain spatial patterns. According to B. Šprocha (2012), the regions with the highest proportion of the population with elementary education as the highest educational level attained (hereinafter referred to as population with elementary education) are characterized particularly by high share of population with low educational aspirations and long-term migration losses associated with the loss of human capital. Such situation is characteristic for peripheral regions and also rural areas which recorded significant migration losses especially under socialist-regime. On the other hand, the highest proportions of population with attained secondary and especially tertiary (university) education are usually recorded in major urban and university centres. Changes in migration and natural reproduction of population behaviours as well as educational systems are supposed to change this patterns to some extent.

Considering findings by V. Lauko et al. (2012) and B. Šprocha (2012), the highest proportion of population with tertiary education in Slovakia was recorded in Bratislava followed by Košice at the beginning of 1990s. The outstanding position of these two cities has remained till the present but the proportion of this category of population increased significantly (also in comparison with general significant increase in Slovakia) also in another centres of university education such as Banská Bystrica, Nitra, Žilina, Prešov, Martin and Zvolen. The research results by V. Lauko et al. (2012) also suggest that the increase of the proportion of population with tertiary education was more significant in predominantly rural hinterlands than in the major cities and towns themselves, during the intercensal period 2001-2011. This indicates quite clearly the impact of suburbanization. 
The authors dealing with the current trends in urban development in Central European countries (e.g. Šnejdová 2006; Ouředníček, Bičík and Vágner 2007; Kurek, Gałka and Wójtowicz 2014) agree that the decentralization of population from the cities to their hinterlands is to large extent driven by migrants with higher incomes. These are usually linked to the higher educational attainment of migrants. Therefore, in certain circumstances, the communities in the hinterlands receiving migrants from the core are supposed to record quantitative improvement of educational structure of population more intensive in comparison with other communities. On the other hand, P. Matejů and J. Straková (2003) emphasize that the family environment is significant factor affecting the educational aspirations of individuals. This indicates possible impact of natural reproduction of population to its educational structure.

Therefore, the aim of this paper is to assess statistically the relationship between basic components of spatial reproduction of population (migration and natural reproduction), and changes in the educational structure of population in the Košice functional urban region. To make the results clear and comparable in the inter-national context, particularly the proportion of population with elementary (primary) and tertiary (university) education is analysed. Next two sections introduce spatial units and methods applied in the research. Following section is focused on analysis of development of spatial redistribution of population processes in terms of migration and natural reproduction of population in the Košice FUR. This is followed by the sections dedicated to the results of analysis of educational structure of population in the region and the analyses of relations between identified processes of spatial redistribution and changes in educational structure of population at the level of individual communities in the region.

\section{Spatial frame}

The main spatial unit of this research is the Košice functional urban region (FUR). FURs, in contrast to administrative units, define the sphere of influence of the core city by commuting. Since the region's core is the city with the concentration of employment and surrounding ring is an area tied to the city by daily commuting, it can be assumed that it is possible to change the place of residence within the region without changing the place of employment. The spatial extent of the Košice FUR was taken from the study by A. Bezák (2000), where FURs in Slovakia were delimited on the basis of the data from the 1991 population census. These FURs are internally coherent and externally relatively closed, when daily commuting is taken into account. Considering these characteristics of FURs it is possible to distinguish between inter-regional and intra-regional migration and its impact to the changes of structure of population, as the inter-regional migration is usually related to the change of place of work 
(economically motivated migration) while the intra-regional is usually driven by change of social status and/or seeking better environmental conditions of residence (cf. Bezák 2000). A. Bezák (2014) published also newer delimitation of FURs in Slovakia, according to results of 2001 population census (those based on 2011 census were not published as the author does not consider the census results to be reliable enough to provide reliable regionalization) but the changes in comparison with those based on 1991 census were not significant. To use the same spatial frame during whole period of observation, the delimitation on the basis of 1991 census (Bezák 2000) in used in whole research.

Each FUR consists of the core (urban centre) and the ring (communities tied with the core by daily commuting). The ring of the Košice FUR consists of 123 communities including two towns, and six localities which are administratively part of the Košice city but are largely rural in nature and spatially separated from the urban core. The core of the Košice FUR consists of 16 spatially more or less integrated city-districts. It is located in South-Eastern Slovakia and shares southern border with Hungary (fig. 1). The number of inhabitants according to 2011 population census was over 363000 . Approximately two thirds lived in the core $(230000)$ and one third in the ring (133000).

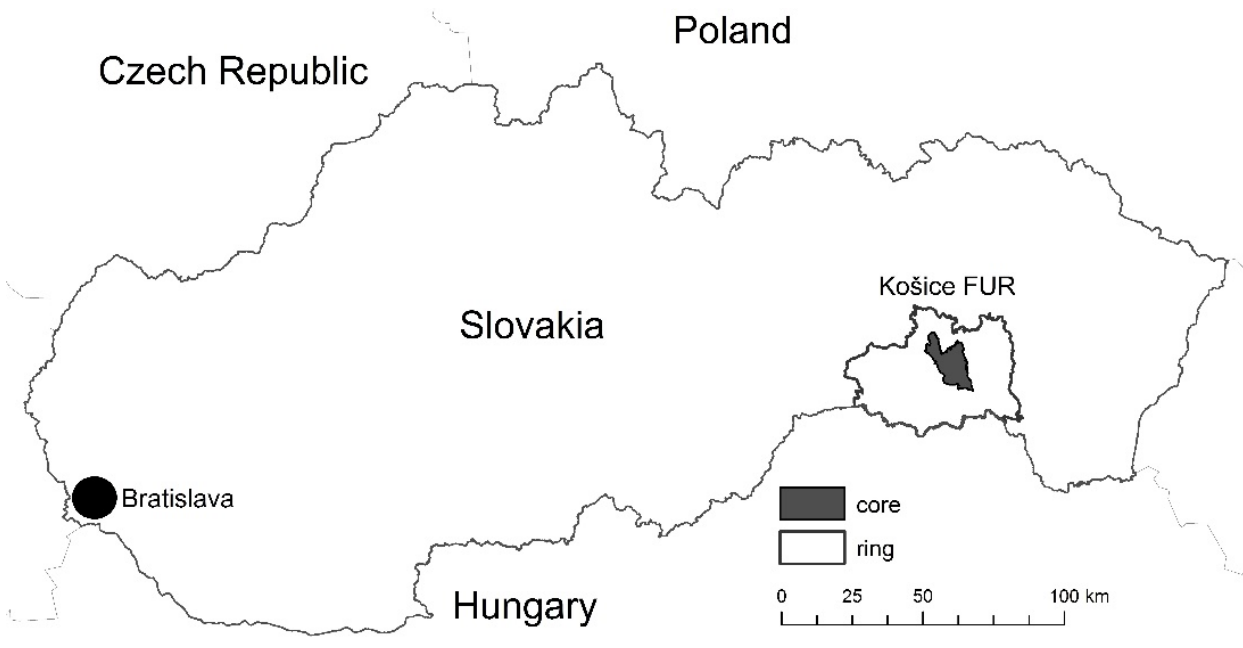

Fig. 1. Location of the Košice functional urban region within Slovakia Source: own compilation

\section{Methods}

Net reproduction rate (often referred to also as the rate of natural increase) and net migration rate calculated as a ratio of natural increase/net migration and mid-year population of given spatial unit, expressed in per mille, are used to assess 
the trends of spatial redistribution of population. To reduce the impact of short-term fluctuations, in some analyses the original values are replaced by the three-year moving averages which values are attributed to the middle of three-year period (i.e. the value of net migration rate for 2008 is represented by the average annual rate for the period 2007-2009). Therefore, the graphic representation of these analyses is reduced to $1992-2012$.

To express the spatial redistribution of population, mainly in terms of migration, different names for processes taking place are used. To avoid confusion, in this paper, in line with B.J.L. Berry and D. Kasarda (1977), J. Grzeszczak (1996), and A. Lisowski (2005), term concentration is used to identify the process of grouping people into a region, and deconcentration for the opposite. Within the region, centralization refers to the process of grouping people into the region's core and decentralization the process of its dispersion from the core to the ring.

When analysing educational structure of population in Slovakia, the indicators referring to the proportion of population with given educational attainment at the total population over 16 years of age (2001 census) or 15 years of age (1991 census) used to be applied. However, the results of 2011 population census provided by SOSR (2011) includes population even from 0 to 16 years of age to the category "without education" if not finished at least elementary school. Nevertheless, some of young people finish elementary school before the age of 16. Therefore, it is not possible to obtain reliable values comparable with results from previous censes by simple subtraction of number of people up to 16 years of age from the number of people "without education". To obtain comparable results from all analysed censes, the educational structure of population in this paper is analysed by simple indicator - a share of certain group by the highest educational attainment on the total population of given spatial unit also for the data from 2001 and 1991 censes.

All statistical data analysed were provided by Statistical Office of Slovak Republic (SOSR). Chosen period 1991-2013 enables the assessment of migration and natural reproduction of population development in different circumstances of post-socialist transformation in Slovakia. The period 1991-2000 is characterized rather by economic decline and worsening of social situation in the country accompanied by the break-down of former natural reproduction and migration patterns (see Bezák 2006 and Mládek 2008), while the period after 2001 is characterized by economic growth and formation of new patterns of reproduction and migration.

The data necessary to calculate the net reproduction rate and net migration rate are based on Annual Registration of Population at the Level of Communities (SOSR 1991-2013). The educational structure of population at the level of individual communities is not published annually by SOSR, therefore data from population censes 2001 and 2011 were used to assess the changes in this aspect of population structure. 
All the data are available for individual communities and the values for functional urban region and its basic components (core and ring) were obtained by grouping those data. The strength of the relationship between the changes in values of educational structure of population indicators and processes of spatial redistribution of population indicators at the level of individual communities are expressed by Pearson's correlation coefficient.

\section{Migration and natural reproduction development}

Despite significant decline of net reproduction rate values during the $1990 \mathrm{~s}$ (from over 6 to less than 2\%), natural reproduction of population played decisive role in the total population growth of the region as whole. The values of net reproduction rate started to grow steadily after 2000 to reach over 3.5\% in 2010 and then started to decline again (fig. 2). The development in the Košice region is very similar with that observed in Slovakia as whole but the values in the Košice FUR are significantly higher.
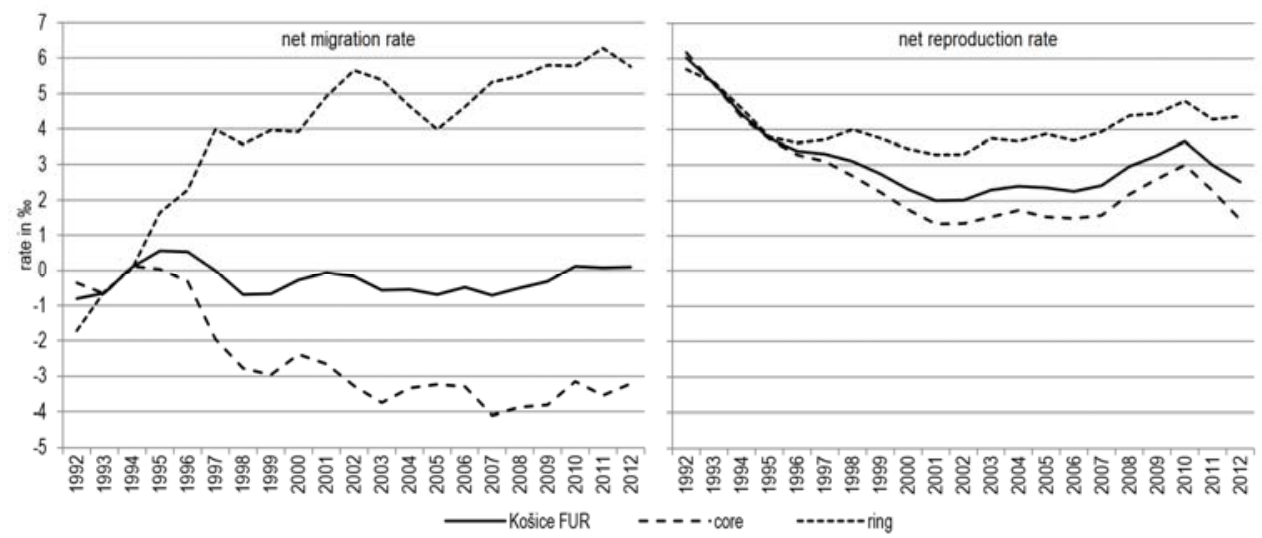

Fig. 2. Changes in migration and natural reproduction in the Košice functional urban region and its basic components in 1991-2013

Source: SOSR (1991-2013)

Migration balance in the Košice FUR as whole was nearing equilibrium during whole period of observation (fig. 2) with negative values of net migration rate dominating. This means the process of deconcentration of population took place in terms of migration, although its intensity was very low.

Major differences between impact of migration and natural reproduction of population to the spatial redistribution of population are seen at intra-regional level. The values of net reproduction rate were similar in the ring and in the core during whole period of observation, but development of net migration rate values was diverse at this level (fig. 2). In the early 1990s, the process of 
centralization of population took place as the net migration rate values were higher in the region's core than in the ring (although both were negative). This might be seen as a residue of socialist-era migration patterns determined by the planned urbanization. After short period in mid-1990s new pattern of migration started to be evident. The migration losses in the core were deepening while the migration gains in the ring increased considerably. The process of centralization with low intensity changed into decentralization with growing intensity during almost whole period of observation. In this regard, migration became driving force determining the intra-regional redistribution of population.

More dynamic development of migration in comparison with natural reproduction of population is apparent also at the level of individual communities in the region's ring (tab. 1). When considering natural reproduction, the proportion of communities recording negative balance grew from 35\% during intercensal period 1991-2000 to 48\% during 2001-2010 at the expense of those with positive balance recorded. During 2011-2013 period this proportion declined to $30 \%$. This development reflects general trends of decline in natural growth of population in Slovakia after 1990 and its temporal slight increase in late 2000s.

Table 1

The numbers and the proportions of communities according to annual average net reproduction rate and net migration rate in the Košice functional urban region

\begin{tabular}{|c|c|c|c|c|c|c|c|c|c|}
\hline \multirow[b]{2}{*}{ Rate } & \multirow[b]{2}{*}{ Period } & \multicolumn{2}{|c|}{-10.01 and less } & \multicolumn{2}{|c|}{$-10.00--0.01$} & \multicolumn{2}{|c|}{$0.00-10.00$} & \multicolumn{2}{|c|}{10.01 and more } \\
\hline & & no & $\begin{array}{l}\text { share } \\
\text { in } \%\end{array}$ & no. & $\begin{array}{l}\text { share } \\
\text { in } \% \\
\end{array}$ & no. & $\begin{array}{l}\text { share } \\
\text { in } \%\end{array}$ & no. & $\begin{array}{l}\text { share } \\
\text { in } \%\end{array}$ \\
\hline \multirow{3}{*}{ 兽 } & 1991-2000 & 7 & 5.7 & 36 & 29.3 & 69 & 56.1 & 11 & 8.9 \\
\hline & 2001-2010 & 5 & 4.1 & 54 & 43.9 & 55 & 44.1 & 9 & 7.3 \\
\hline & 2011-2013 & 5 & 4.1 & 32 & 26.1 & 71 & 57.7 & 15 & 12.2 \\
\hline \multirow{3}{*}{ 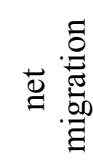 } & 1991-2000 & 10 & 8.1 & 43 & 35.0 & 60 & 48.8 & 10 & 8.1 \\
\hline & 2001-2010 & 2 & 1.6 & 22 & 17.9 & 73 & 59.3 & 26 & 21.1 \\
\hline & 2011-2013 & 0 & 0.0 & 21 & 17.1 & 102 & 82.9 & 0 & 0.0 \\
\hline
\end{tabular}

Source: SOSR (1991-2013).

Similarly with natural reproduction, majority of communities was recording positive migration balance during whole period of observation. When comparing first two observed intercensal periods, the proportion of communities gaining population by migration grew from $57 \%$ to over $80 \%$ at the expense of the proportion of communities with migration losses. The impact of decentralization of population is even more apparent in the growth of the share of communities with significant migration growth (annual average net migration rate over 10\%) as it grew more than 2.5 -fold (tab. 1). The proportion of communities with 
positive migration balance grew also after 2011 but in the same time, no community exceeded $10 \%$ value of net migration rate. This might be result of halt and even slight decline of decentralization intensity after 2010 (fig. 2). However, the period 2011-2013 is relatively short to conclude if the development observed is only short-term deviation or it is a beginning of new trend.

Generally, the dominant trend at regional level in the Košice FUR is the concentration of population which is driven by natural reproduction and reduced by very slight deconcentration of population by migration. The dominant role at the spatial redistribution of population between the region's core and ring plays migration, which is responsible for decentralization of population with low intensity (and the shift from centralization) during the 1990s but strong intensity during the 2000s (see more in: Novotný 2014).

\section{Educational structure of population in the region, its core and ring}

Educational structure of population in a particular region reflects its level of social and cultural development. The Košice FUR, which core is after Bratislava the second largest and most important university centre in Slovakia, proves its extraordinary position also by relatively high share of population with tertiary education and relatively low share of population with elementary education.

Changes in educational structure of population that occurred in the region during the reference period could be affected by many factors. Within the overall transformation of society after 1989, the transformation of education system took place, resulting into establishment of new universities and their branches. The number of students and graduates grew significantly what led to quantitative improvement of educational structure of population. Extension of the elementary education from eight to nine years could also affect the resulting values but negligible in terms of overall development. Nevertheless, the migration and natural reproduction of population are among the most important phenomena that can affect the educational structure of population at both, inter-regional and intra-regional levels.

In 1991, the share of population with the elementary education at the total population of the Košice FUR was $24.5 \%$, more than four percentage points (PP) less than in Slovakia as whole (28.7\%). Slightly smaller difference (3.4 PP) was recorded in 2001 and even smaller (2.6 PP) in 2011, when the proportion of population with elementary education reached $12.4 \%$ in the Košice FUR and $15.0 \%$ in Slovakia. Despite narrowing the gap, the Košice FUR remains the region with considerably lower value of this indicator in the national context.

Population in larger towns and cities, in comparison with rural areas, is characterized by better educational structure of population with relatively high proportion of university graduates and low proportion of population with the elementary education. This corresponds with the different proportions of both 
analysed categories of population between the urban core and predominantly rural ring of the Košice FUR (fig. 3, 4).

The share of population with elementary education at the total population of the region's core was $19.6 \%$ and in the ring $34.5 \%$. The difference of almost 15 PP in 1991 narrowed to 12 PP in 2001, and in 2011 it only slightly exceeded $10 \mathrm{PP}$, as the proportion in the core was $8.7 \%$ and in the ring $18.9 \%$. The decrease in the share of population with elementary education between 1991 and 2011 was 10.9 PP in the core and 15.6 PP in the ring (fig. 3).

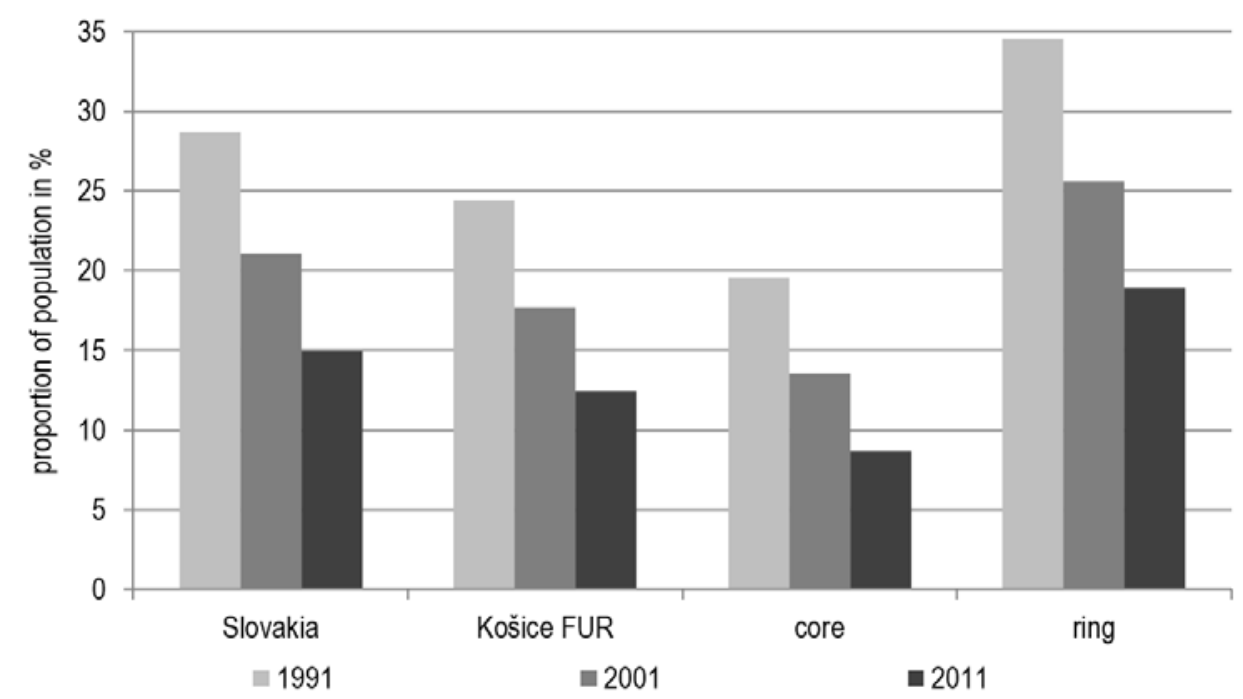

Fig. 3. The proportion of population with elementary education at the total population of the Košice functional urban region, its components and comparison with Slovakia in 1991, 2001 and 2011

Source: SOSR $(1991,2001,2011)$

Changes with similar intensity but opposite nature are recorded in the analysis of population with tertiary education. Its proportion at the total population of the region was $7.8 \%$ in 1991, two percentage points more than at whole population of Slovakia (5.8\%). By 2001, the value of this indicator grew to $7.9 \%$ in Slovakia but in the Košice FUR even to $10.2 \%$ so the difference increased to 2.3 PP. Almost the same difference was recorded in 2011, when the proportion of tertiary educated people reached $13.9 \%$ in Slovakia and $16.2 \%$ in the region (fig. 4). Halting growth of the difference between Slovakia and the Košice FUR might be partially seen as a result of development of a network of universities and their branches in the regions of Slovakia, even out of the traditional university centres. 


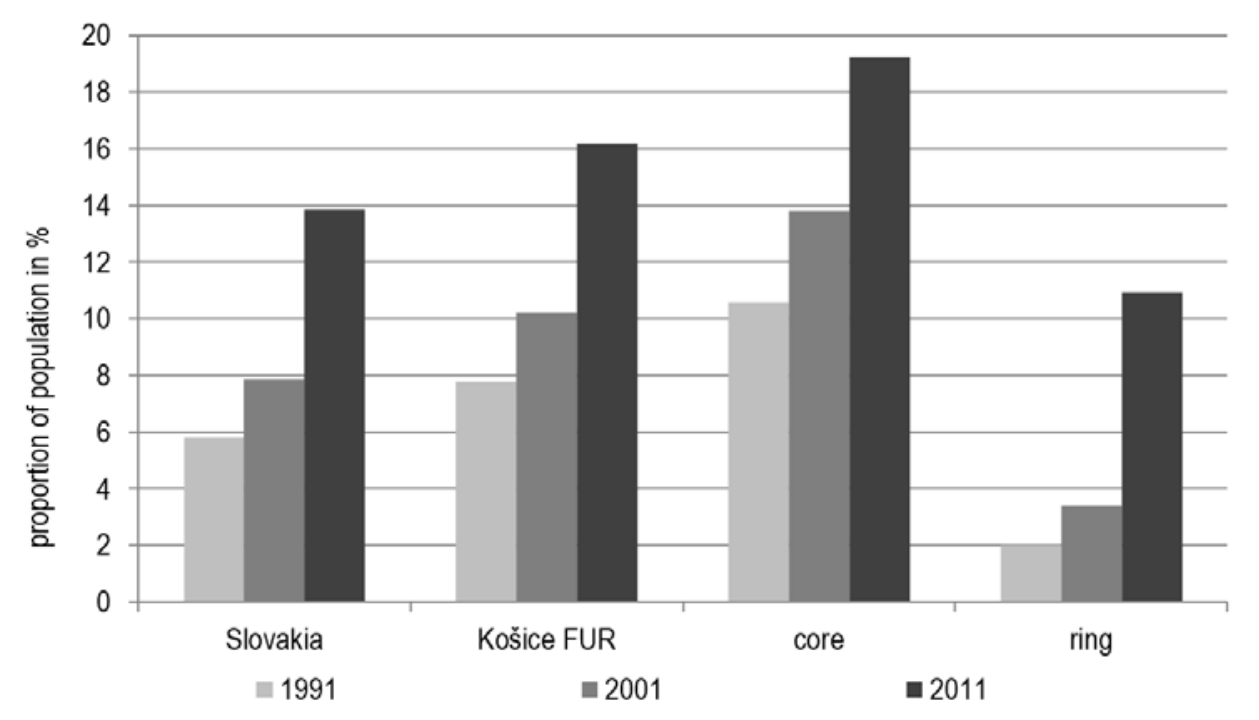

Fig. 4. The proportion of population with tertiary education at the total population of the Košice functional urban region, its components, and comparison with Slovakia in 1991, 2001 and 2011

Source: $\operatorname{SOSR}(1991,2001,2011)$

In the region's core, $10.6 \%$ of total population attained tertiary education by 1991 but in the ring it was only $2.0 \%$. The proportion of this category of population in the core grew to $13.8 \%$ by 2001 and to 19.2 by 2011 . This represents the growth between 1991 and 2011 by $8.6 \mathrm{PP}$. The growth in the ring was only modest to $3.4 \%$ by 2001 but in 2011 the proportion reached $10.9 \%$ what makes the difference 8.9 PP in comparison with 1991. However, noteworthy is the growth of the proportion of tertiary educated people between 2001 and 2011, when intensive decentralization of population took place. During this period the growth of the university graduates share at total population amounted to $7.5 \mathrm{PP}$ in the ring while in the core it was only 5.4 PP.

More intensively decreasing proportion of the population with elementary education and increasing proportion of the population with tertiary education in predominantly rural ring of the Košice FUR in comparison with its core may be to some extent caused by significantly larger proportion of the population with elementary education and very small proportion of tertiary educated population at the beginning of observation. However, the development observed correspond to findings by I. Šnejdová (2006), M. Ouředníček, I. Bičík and J. Vágner (2007), S. Kurek, J. Gałka and M. Wójtowicz (2014) and may be attributed to intensive decentralization of population from the core to the ring ongoing especially during the 2001-2011 period. 


\section{Relation between changes in educational structure of population and processes of spatial redistribution of population at the level of individual communities}

The analysis at the level of individual communities is conducted for the intercensal period 2001-2011, when new patterns of migration and natural reproduction of population are distinct, and processes of spatial reproduction of population at intra-regional level are relatively intensive. Declines in the proportion of population with elementary education is evident also at the level of individual communities. Spatial distribution of communities categorized according to acquired values of this indicator in 2001 as well as in 2011 is characteristic for concentration of communities with low proportions of population with elementary education in the proximity of the region's core and those with high shares mainly at the periphery of the region (fig. 5).

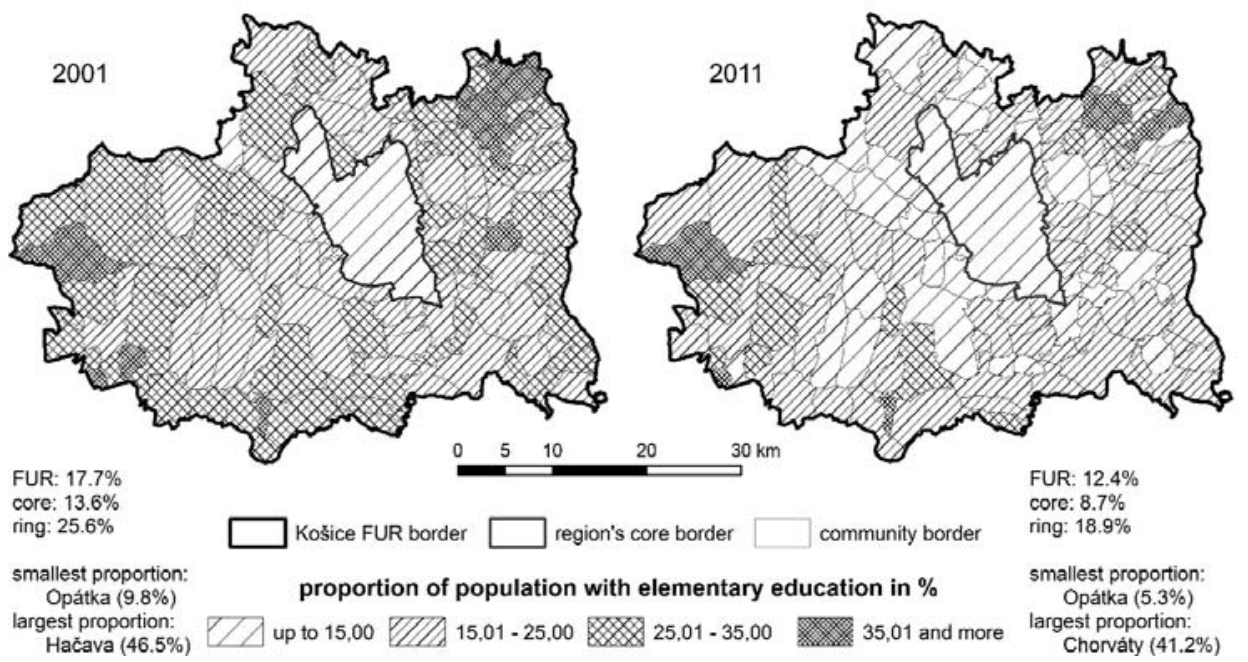

Fig. 5. The proportion of population with elementary education in total population of communities of the Košice functional urban region in 2001 and 2011

Source: SOSR $(2001,2011)$

Populations of several communities with relatively high share of population with elementary education have also significant share of Roma people according to estimations from Atlas of Roma Communities ${ }^{2}$ (Jurásková et al. 2004). On the

${ }^{2}$ Among the ethnic minorities in Slovakia, probably the most specific social, cultural, as well as reproductive and migration behaviour is characteristic for Roma population. Capturing of proportion and spatial distribution of this population is very difficult, as majority of Roma people claims Slovak (or Hungarian in communities with prevailing 
other hand, there are some communities without any Roma population but with high proportion of population with elementary education.

Considering changes in the proportions of population with elementary education between 2001 and 2011, no distinct relation with the communities' distance from the core or any other spatial pattern (fig. 6) is observable. This may be result of certain spatial structure of communities according to the values of analysed indicator already in 2001. Only three communities recorded increase in the proportion of population with elementary education. The largest increase was recorded in the Rankovce community, where approximately three fourths of total population are Roma people. On the other hand, there were no Roma people recorded in remaining two communities. The largest declines in the values of analysed indicator were recorded by communities in the proximity of the core but also by some communities in peripheral areas, especially those with high proportion of population with elementary education in 2001.

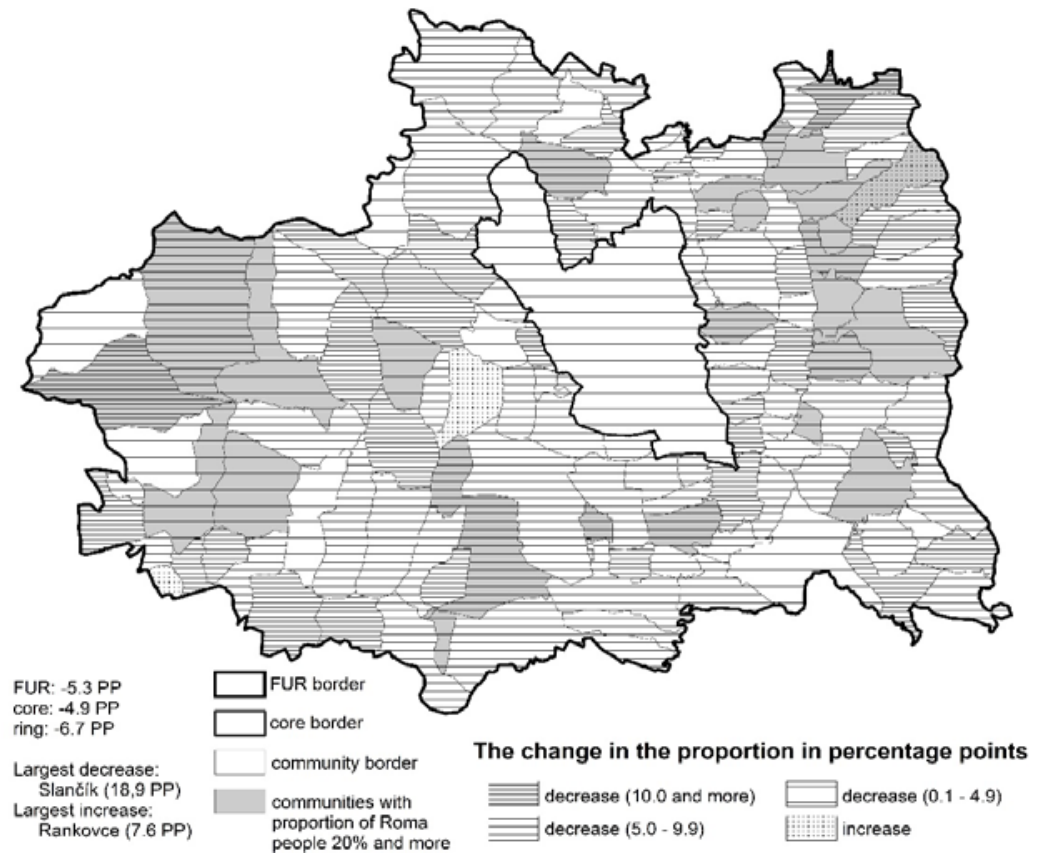

Fig. 6. Change in the proportion of population with the elementary education as the highest educational level attained at the total population of communities in the Košice functional urban region between 2001 and 2011

Source: SOSR (2001, 2011), M. Jurásková et al. (2004)

Hungarian ethnicity) ethnicity in the population censes. Therefore, also specific characterristics of this ethnic minority might be statistically attributed to Slovak or Hungarian population. To estimate real proportion of Roma people in individual communities, data from Atlas of Roma Communities are used. 
Spatial differentiation of communities according to the proportion of the population with tertiary education is not significant in the region's ring in 2001. Over $86 \%$ of communities (106 out of 123 ) recorded the value below $5 \%$. Only 17 communities exceeded $5 \%$ share of population with tertiary education, including the only one exceeding $10 \%$. Much more distinct spatial stratification in this context formed by 2011. The number of communities with the proportion of people with tertiary education at total population below $5 \%$ declined to $11(9 \%)$, while the number of those with given indicator value over $10 \%$ increased from 1 to $60(49 \%)$. The concentration of communities with the highest proportion of university graduates in the region's core proximity is clear (fig. 7).

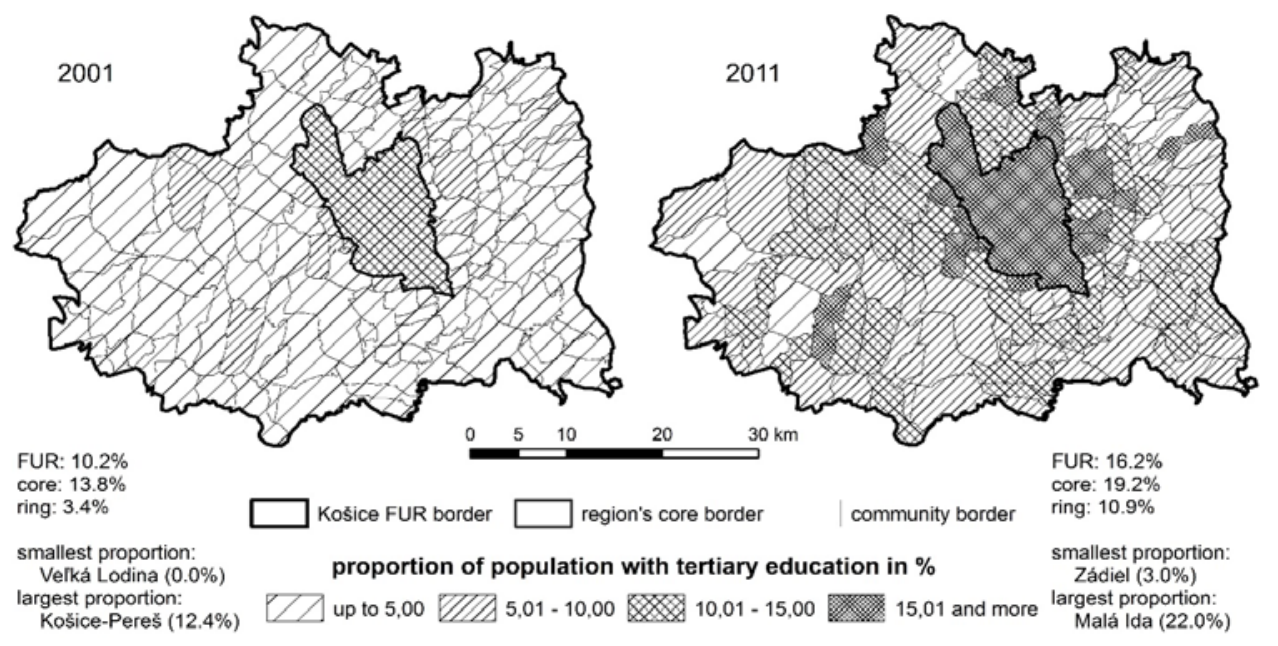

Fig. 7. The proportion of population with tertiary education in total population of communities of the Košice functional in 2001 and 2011

Source: SOSR $(2001,2011)$

Unlike the case of population with the elementary education, communities with the largest increases in the proportion of population with tertiary education are located mainly in the close hinterland of the region's core. On the other hand, majority of communities with smallest increases is located in the peripheral parts of the region (fig. 8). Moreover, majority of communities with the low decrease or even increase in the proportion of population with elementary education, as well as communities with the lowest increase of proportion of population with tertiary education has significant (over 20\%) proportion of Roma people in their populations. 


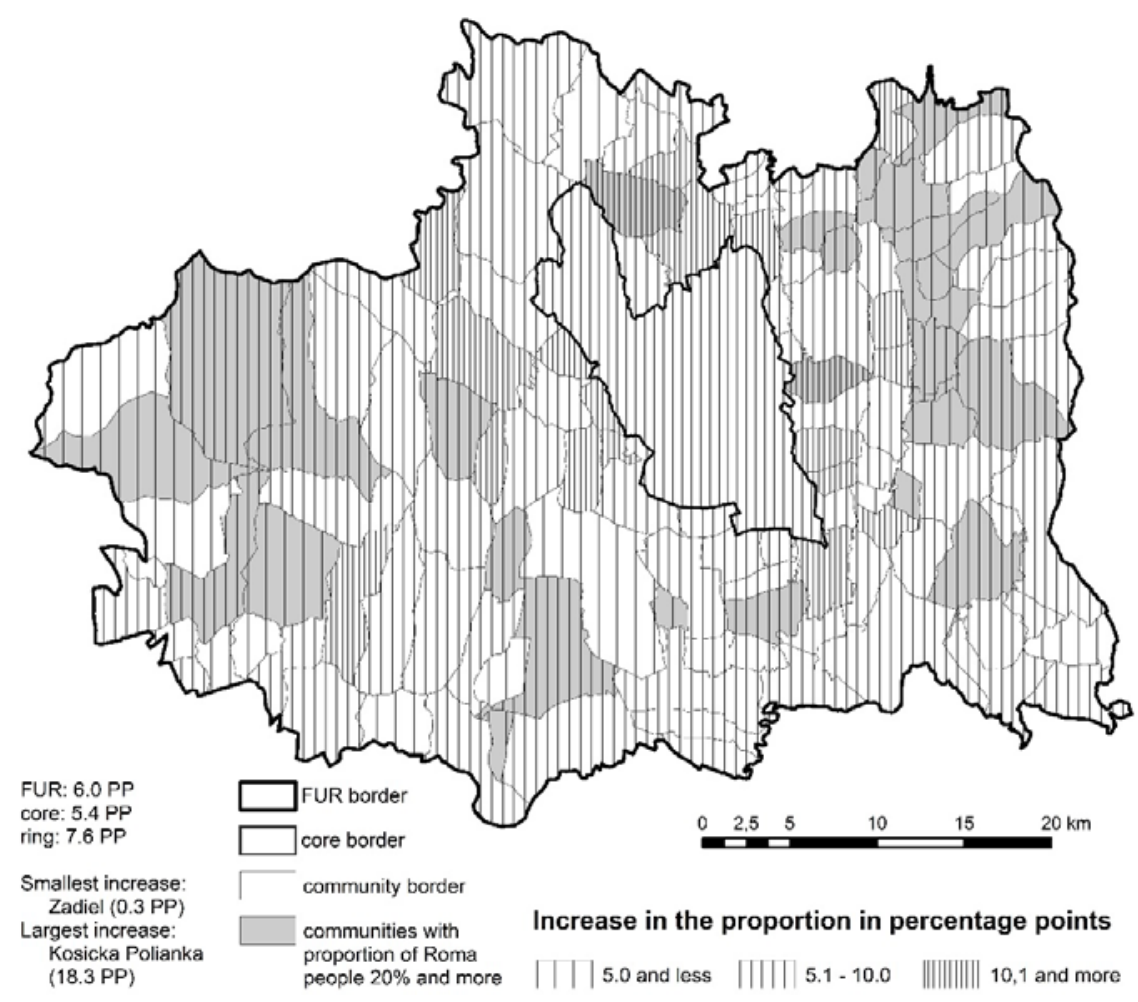

Fig. 8. Change in the proportion of population with the tertiary as the highest attained education at the total population of communities in the Košice functional urban region between 2001 and 2011

Source: SOSR (2001, 2011), M. Jurásková et al. (2004)

Proportions of population with chosen level of highest education attainment, and their changes indicate certain relationship with the ongoing process of decentralization of population which is driven predominantly by migration. However, considering correlation analysis of this development, it is clear that the impact of decentralization is selective to various categories of population according its education attainment (fig. 9, 10).

In case of changes in the proportion of population with elementary education as the highest education attained, the impact of migration and natural reproduction of population indicates contradictory character. The relationship between the change in the proportion of population with elementary education at the total population and the values of net reproduction rate in individual communities has character of medium to strong (cf. Cohen 1977³) positive

${ }^{3}$ In line with J. Cohen (1977), weak (Pearson's correlation coefficient from 0.1 to 0.3 , medium (0.3-0.5) and strong (over 0.5 ) relationship might be distinguished when considering linear correlation in social phenomena. 
correlation. In contrary, the relationship with net migration rate values has character of weak negative correlation (fig. 9). With a considerable degree of generalization it is possible to state that communities recording higher values of net migration rate tend to record rather stronger decline in the proportion of this category of population, due to significant dispersion of values it is not possible to label this relationship as regularity.
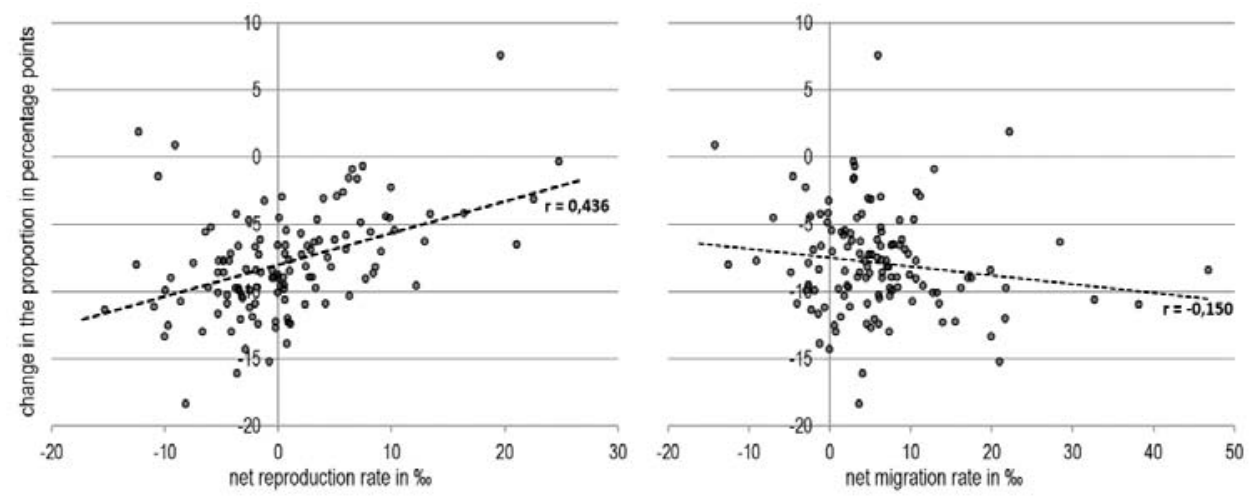

Fig. 9. Relationship of changes in the proportion of population with elementary education as the highest education attained at the total population and the values of net reproduction and net migration rate in the communities of the Košice functional urban region during the period 2001-2011 expressed as linear correlation Source: SOSR (1991-2012, 2001, 2011)

Thus it is possible to conclude that decisive role in the development of the proportion of population with elementary education still plays natural reproduction of population in predominantly rural ring of the Košice FUR. This confirms relatively strong resistance of specifics in demographic, especially reproductive behaviour of population with low education attainment level (cf. Gazda 2014). Considerable share in this social and educational class is represented by Roma ethnic group living in worse social and economic conditions, and recording high values of natality. The Košice region is among regions in Slovakia recording the largest proportion of Roma people in its total population. This may explain to some extent, why the difference between the share of population with elementary education in the region and in Slovakia as whole is narrowing (fig. 3).

Relationship of changes in the proportion of population with tertiary education has character of weak negative correlation with the values of net reproduction rate. However, medium positive correlation is recorded with the 
values of net migration rate, despite significant dispersion of its values ${ }^{4}$ (fig. 10). This indicates decisive role of migration in the changes of distribution of population with tertiary education in the Košice FUR's ring. This confirms important role of migrants with high social status related usually with university education, in the process of decentralization of population from the region's urban core to predominantly rural hinterland.
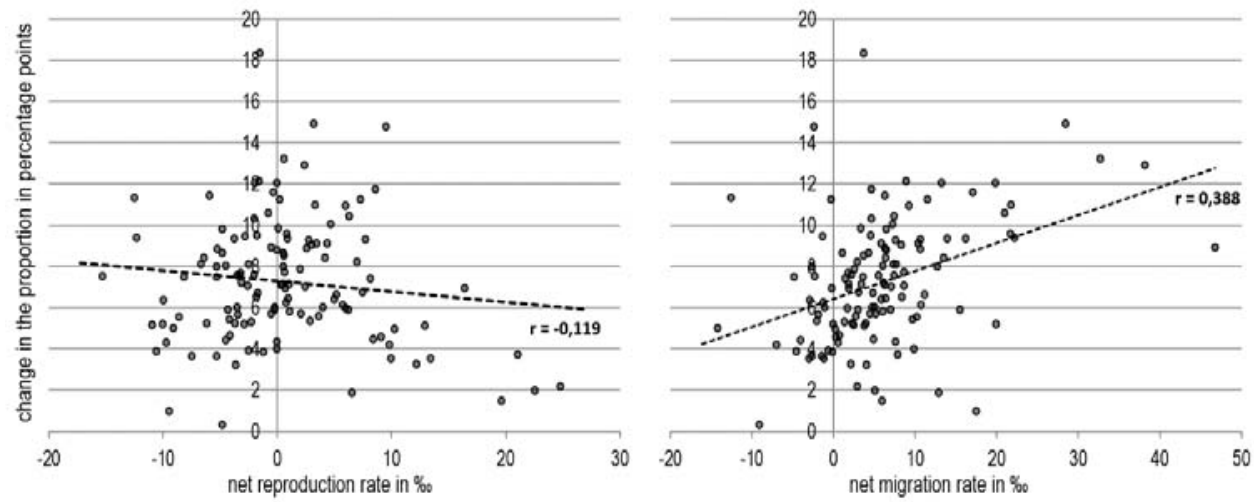

Fig. 10. Relationship of changes in the proportion of population with tertiary education attained at the total population and the values of net reproduction and net migration rate in the communities of the Košice functional urban region during the period 2001-2011 expressed as linear correlation

Source: SOSR (1991-2012, 2001, 2011)

\section{Conclusions}

Trends of spatial redistribution of population in the Košice functional urban region (FUR) recorded fundamental transformation since the early 1990s. In line with general trends in Slovakia, natural increase of population declined but in the examined region remained positive during whole period 1991-2013. The patterns of migration from socialist era broke down in the early 1990s and after transformation during mid-1990s, new patterns characteristic by decentralization of population from the region's core to the ring formed. The process of decentralization of population driven mainly by migration became very intensive especially after 2000 and became determinant factor of spatial redistribution of population within the region.

\footnotetext{
${ }^{4}$ If four communities with most extreme values were omitted from the analysed set, the value of Pearosn's correlation coefficient would exceed 0,5 so the correlation would become strong.
} 
Development of educational structure of population in the Košice FUR reflects general trends in Slovakia, which are characteristic also for majority of other CEE countries. Changes in state policies led to increase in number of universities and their branches, as well as in the number of university graduates. From quantitative point of view, the educational structure of population in Slovakia recorded significant improvement since the collapse of socialist regime.

Decrease in the proportion of population with the elementary education as the highest educational level attained and increase in the proportion of population with tertiary education was reflected in urban as well as in rural areas that are usually characterized by worse educational structure of population than urban areas. However, it is not possible to interpret all recorded changes only by the changes in educational system. Analysis in the Košice FUR proved, that the improvement of educational structure of population was faster in predominantly rural ring than in the region's urban core, what seems to be result of worse educational structure in the ring than in the core at the beginning of analysis, as well as the processes of spatial redistribution of population taking place in the region.

The analysis at the level of individual communities proved selective impact of migration and natural reproduction of population to the changes in proportions of population with the elementary and with tertiary education at the total population of individual communities. Net reproduction rate values showed relatively strong positive correlation with the changes in the proportion of population with elementary education. The correlation with net migration rate values was negative and weak. Despite decrease in net reproduction rate values, the natural reproduction of population remains driving force of changes in spatial distribution of population with elementary education as the highest education level attained. This confirms resistance of specifics in demographic, especially reproductive behaviour of population with low education attainment level and indicates significant impact of Roma people constituting considerable proportion of region's ring population, living in worse social and economic conditions, and recording high values of natality.

Changes in the share or population with tertiary education correlated positively and relatively strongly with the values of net migration rate, while the correlation with net reproduction rate was negative and very weak. This confirms important role of higher social class of population which is usually related to higher educational level attainment, in the process of decentralization of population. And it also confirms decisive role of migration in the spatial redistribution of population with tertiary education attained within the functional urban region. 


\section{BIBLIOGRAPHY}

Berde É., Ványolós I., 2008, Impact of institutional changes on Hungarian higher education after 1989, „Higher Education Quarterly”, 62, pp. 297-317.

Berry B.J.L., Kasarda D., 1977, Contemporary urban ecology, Macmillan Publishing, New York, $498 \mathrm{p}$.

Bezák A., 2000, Funkčné mestské regióny na Slovensku, „Geographia Slovaca”, 15, Geografický ústav SAV, Bratislava.

Bezák A., 2006, Vnútorné migrácie na Slovensku: súčasné trendy a priestorové vzorce, „Geografický as opis”, 58, pp. 15-44.

Bezák A., 2014, Funkčné mestské regióny na Slovensku v roku 2001, [in:] Lauko V. et al. (eds), Regionálne dimenzie Slovenska, Univerzita Komenského, Bratislava, pp. $169-198$.

Cohen J., 1977, Statistical power analysis for the behavioral sciences, Revised edition, Academic Press, London, 474 p.

Gazda M., 2014, Komponenty pohybu obyvatelstva a ich vplyv na vzdelanostnú štruktúru obyvatel'stva vo funkčnom mestskom regióne Michalovce, Diploma thesis, Ústav geografie, Prírodovedecká fakulta UPJŠ, Košice.

Gorga A., 2007, Where are we with harmonization of European higher education? The case of Central and East European countries,,European Education”, 39(4), pp. 58-68.

Grzeszczak J., 1996, Tendencje kontrurbanizacyjne w krajach Europy Zachodniej, „Prace Geograficzne", 167, Continuo, Wrocław.

Jung-Miklaszewska J., 2003, The system of education in the Republic of Poland. Schools and diplomas, Bureau for Academic Recognition and International Exchange, Polish NARIC/ENIC, Warsaw. Available at: http://buwiwm.home.pl/publ/edu/System.pdf.

Jurásková M., Kriglerová E., Rybová J., Radičová I., 2004, Atlas rómskych komunít, Úrad splnomocnenca vlády SR pre rómske komunity, Bratislava, $191 \mathrm{p}$. Available at: http://www.romovia.vlada.gov.sk/3553/atlas-romskych-komunit-2004.php.

Kurek S., Gałka J., Wójtowicz M., 2014, Wpływ suburbanizacji na przemiany wybranych struktur demograficznych i powiazań funkcjonalno-przestrzennych w Krakowskim Obszarze Metropolitalnym, Wydawnictwo naukowe Uniwersytetu Pedagogicznego, Kraków, 231 p.

László B., 2008, The impact of the Bologna process on higher education in Slovakia, „European Education”, 40(2), pp. 46-65.

Lauko V., Gurňák D., Križan F., Tolmáči L., 2012, Najnovšie vývojové trendy vzdelanostnej štruktúry obyvatel'stva Slovenska v časovo-priestorových súvislostiach, „Geographia Cassoviensis", 6(2), pp. 91-102.

Lisowski A., 2005, Procesy centralizacji i decentralizacji w Aglomeracji Warszawskiej w latach 1950-2002, „Prace i Studia Geograficzne”, 35, pp. 13-44.

Matejů P., Straková J., 2003, Role rodiny a školy v reprodukci vzdělanostných nerovností, „Sociologický časopis”, 39, pp. 625-652.

Mládek J., 2008, Stabilizácia populačného vývoja Slovenska na úrovni stacionárnej populácie, „Acta Geographica Universitatis Comenianae”, 50, pp. 63-78. 
Nestorová-Dická J., 2013, Vysoké školstvo v krajinách Vyšehradskej štvroky v čase postsocialistickej transformacie, „Acta Geographica Universitatis Comenianae”, 57, pp. 195-2011.

Novotný L., 2014, Procesy priestorovej redistribúcie obyvatel'stva a ich vplyv na zmeny štruktúry obyvatel'stva vo funkčnom mestskom regióne Košice, Univerzita Pavla Jozefa Šafárika, Košice, 136 p.

Ouředníček M., Bičík I., Vágner J., 2007, Suburbanizace v zázemí Prahy, „Životné prostredie", 41, pp. 303-306.

SOSR 1991-2013, Annual registration of population at the level of communities, Statistic Office of Slovak Republic - SOSR, Bratislava.

SOSR 1991, Results of population census 1991, Statistic Office of Slovak Republic SOSR, Bratislava.

SOSR 2001, Results of population census 2001, Statistic Office of Slovak Republic SOSR, Bratislava. Available at: http://sodb.infostat.sk/sodb/eng/2001/format.htm.

SOSR 2011, Results of population census 2011, Statistic Office of Slovak Republic SOSR, Bratislava. Available at: http://census2011.statistics.sk/.

Šnejdová I., 2006, Změny ve vzdělanostni struktuře obyvatelstva Pražského městského regionu, [in:] Ouřednícek M. (eds.), Sociální geografie Pražského městského regio$n u$, Univerzita Karlova, Př́rodovědecká fakulta, kat. sociální geografie a regionálního rozvoje, Praha, pp. 114-127.

Šprocha B., 2010, Vývoj vzdelanostnej štruktúry a vzdelávania na Slovensku, „Slovenská štatistika a demografia", 20(1), pp. 3-30.

Šprocha B., 2012, Regionálne disparity dosiahnutého vzdelania na Slovensku a ich vývoj $v$ poledných dvoch desatročiach. Reprodukce lidského kapitálu - vzájemné vazby a souvislosti, Vysoká škola ekonomická, Praha.

Vincze S., Harsányi G., 2012, Hungarian higher education and its international comparison, [in:] Farkas B., Mezö J. (eds.), Crisis aftermath: economic policy changes in the EU and its member states conference proceedings, University of Szeged, Szeged, pp. 496-513.

\section{PROCESY REDYSTRYBUCJI PRZESTRZENNEJ LUDNOŚCI A ZMIANY W STRUKTURZE JEJ WYKSZTALCENIA. STUDIUM PRZYPADKU REGIONU MIEJSKIEGO KOSZYC}

Zarys treści: $\mathrm{W}$ artykule skoncentrowano się na procesach redystrybucji przestrzennej ludności w odniesieniu do zmian w strukturze wykształcenia. Przemiany w tym zakresie przedstawiono na przykładzie regionu miejskiego Koszyce (Słowacja) - drugiego pod względem wielkości miasta w kraju. Podobnie jak w innych regionach miejskich Europy Środkowej, największe miasta charakteryzuje decentralizacja ludności. Wyludnieniu ulegają obszary rdzeniowe, zwiększa się natomiast liczba ludności w obszarach zewnętrznych regionów miejskich. Podczas gdy przyrost naturalny ludności powoduje wzrost liczby ludności w całym regionie, to proces migracji jest selektywny i decyduje o zmianach $\mathrm{w}$ przestrzennym rozmieszczeniu ludności. Istnieje związek pomiędzy procesami redystrybucji ludności a zmianami w strukturze wykształcenia w obrębie regionów miejskich. Obszary o wyższych wskaźnikach przyrostu naturalnego charakteryzują się 
niższym poziomem wykształcenia ludności, natomiast tereny, na które napływa ludność (wysokie saldo migracji) cechują się wyższym odsetkiem ludności z wykształceniem wyższym.

Słowa kluczowe: edukacja, reprodukcja ludności, migracje, region miejski, Koszyce.

Dr Ladislav Novotný Institute of Geography

Faculty of Science

Pavol Jozef Šafárik University in Košice 